\title{
APLICAÇÃO DE GEOTECNOLOGIAS NA AGROPECUÁRIA DA MICRORREGIÃO GEOGRÁFICA DE ITUIUTABA/MINAS GERAIS ${ }^{1}$
}

\section{APPLICATION OF GEOTECHNOLOGIES IN THE AGRICULTURE OF THE GEOGRAPHICAL MICRO-REGION OF ITUIUTABA/MINAS GERAIS}

\author{
Roberto Barboza Castanho \\ Doutor em Geografia, Universidade Federal de Uberlândia, Instituto de Ciências Humanas do Pontal, \\ Ituiutaba, MG, Brasil \\ rbcastanho@gmail.com
}

Victor Matheus da Cruz de Carvalho Graduado em Geografia, Universidade Federal de Uberlândia, Instituto de Ciências Humanas do Pontal, Ituiutaba, MG, Brasil vmccarvalho15@gmail.com

Guilherme Henrique dos Santos Santana Mestrando em Geografia, Universidade Federal de Uberlândia, Instituto de Geografia, Uberlândia, MG, Brasil guilherme_santana01@ hotmail.com

\begin{abstract}
Resumo
As Geotecnologias se apresentam como um conjunto de ferramentas importantes para a otimização da produção nos mais diversos setores. Neste sentido, esta pesquisa versou sobre investigar o uso e aplicabilidades das Geotecnologias na Microrregião Geográfica de Ituiutaba, Minas Gerais, sendo composta por seis (06) municípios de grande aptidão e produção agropecuária. Assim, como procedimentos metodológicos, efetuou-se um referencial teórico acerca da temática, seguido pela coleta de dados em fontes oficiais. Paralelo a essa etapa, efetuou-se a reambulação no recorte espacial, com a finalidade de averiguar as informações obtidas, bem como obter informações in loco em secretarias de agricultura e setores da EMATER dos municípios. Vencida essa fase, primou-se pela tabulação e análise dos dados, conjuntamente, produzindo o material cartográfico da área, e, por fim, obtiveram-se os resultados finais. Diante disso, infere-se que a área em estudo ainda é incipiente no que tange à utilização das Geotecnologias, sendo que se fazem presentes apenas em alguns setores agropecuários, como na produção sucroenergética, tais como fertilização e mapeamento do uso da terra, visando aumento da produtividade de tal produto. Também se obteve pequenos usos na produção de pecuária de leite, porém, com baixa aplicação dessas ferramentas. Além disso, deve-se enfatizar o potencial a ser explorado pelas Geotecnologias na área, o qual se observa com a instalação de empresas do ramo, que podem atender a esfera agropecuária, tanto neste momento, quanto em um futuro próximo.
\end{abstract}


Palavras-chave: Geotecnologia. Agropecuária. Meio Técnico-Científico-Informacional. MRG Ituiutaba.

\begin{abstract}
Geotechnologies are presented as a set of important tools for the optimization of production in the most diverse sectors. In this sense, this research dealt with investigating the use and applicability of Geotechnologies in the Geographic Microregion of Ituiutaba, Minas Gerais, comprising six (06) municipalities of great aptitude and agricultural production. Thus, as methodological procedures, a theoretical reference was made about the theme, followed by data collection from official sources. Parallel to this stage, field research was performed in the spatial section, with the purpose of verifying the information obtained, as well as obtaining information in loco in agriculture departments and EMATER sectors of the municipalities. After this phase was over, the data were tabulated and analyzed together, producing the cartographic material of the area, and, finally, the final results were obtained. Therefore, it appears that the area under study is still incipient with regard to the use of Geotechnologies, being present only in some agricultural sectors, such as sugar-energy production, such as fertilization and mapping of land use, aiming at increasing productivity of such a product. Small uses were also obtained in the production of dairy cattle, however, with low application of these tools. In addition, the potential to be explored by Geotechnologies in the area must be emphasized, which can be observed with the installation of sector companies, which can serve the agricultural sphere, both at this time and in the near future.
\end{abstract}

Key words: Geotechnology. Agriculture. Technical-Scientific-Informational Environment. MRG Ituiutaba.

\title{
Introdução
}

O presente artigo teve como objetivo, investigar a utilização e aplicabilidades das Geotecnologias no recorte espacial da Microrregião Geográfica de Ituiutaba/MG, que é formada pelos municípios de Ituiutaba, Santa Vitória, Capinópolis, Gurinhatã, Ipiaçu e Cachoeira Dourada (Mapa 01). Sobre esta microrregião, ela está localizada na Mesorregião do Triângulo Mineiro/Alto Paranaíba, no estado de Minas Gerais. 


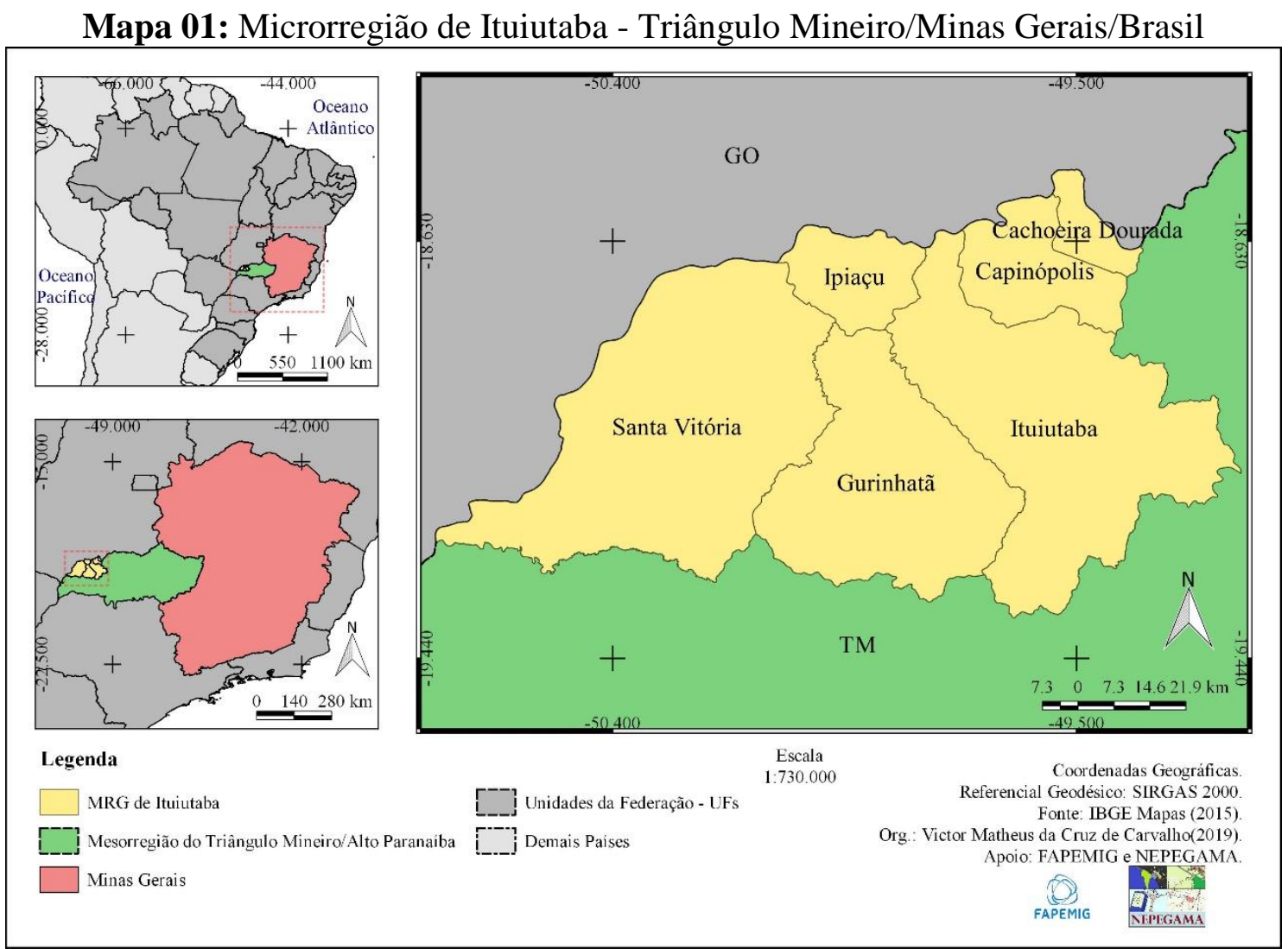

Fonte: IBGE Mapas, 2015.

Org.: Os autores, 2019.

Em síntese, os procedimentos metodológicos estipulados para esta pesquisa foram divididos através das seguintes etapas: $1^{\mathrm{a}}$ etapa - Levantamento bibliográfico sobre o tema, no qual se buscou fazer uma revisão sobre estudos e pesquisas que abordam diversos temas acerca do meio técnico-científico-informacional e geotecnologias na agricultura, além do panorama agropecuário da região, entre outros; $2^{\mathrm{a}}$ etapa - Coleta de dados secundários disponibilizados por órgãos oficiais, tais como a Produção Agrícola Municipal (PAM/IBGE), Instituto de Pesquisa Econômica Aplicada (IPEA) e outros; $3^{\mathrm{a}}$ etapa - Realização de reambulação em campo (trabalho de campo) no recorte espacial condizente à pesquisa, buscando a obtenção de dados e informações complementares que não puderam ser encontradas em fontes secundárias, além de promover o contato direto com a área estudada; $4^{\mathrm{a}}$ etapa - Análise de dados obtidos nas etapas anteriores, sendo levado em consideração todas as variáveis investigadas; $5^{\text {a }}$ etapa - Elaboração e apresentação dos resultados obtidos, de forma a alcançar todos os objetivos propostos para esta investigação, tendo como resposta o grau de utilização das Geotecnologias na agropecuária e quais as aplicabilidades e contribuições na agropecuária regional. 


\section{O meio técnico-científico-informacional no campo brasileiro.}

Não há como discutir o campo moderno no Brasil sem considerar a inserção do meio técnico-cientifico-informacional e sua posterior territorialização num contexto de Revolução Verde, de grandes investimentos e modernização agrícola. Para Santos (1994), o meio técnico-científico-informacional é caracterizado em incorporar e requalificar os espaços para que atendam os interesses dos atores hegemônicos e sejam colocados sobre característica econômicas e de sociedade, ligados às correntes da globalização.

O meio técnico-científico-informacional é a nova cara do espaço e do tempo. É aí que se instalam as atividades hegemónicas, aquelas que têm relações mais longínquas e participam do comércio internacional, fazendo com que determinados lugares se tornem mundiais. (SANTOS,1994, p. 21).

Logo, observa-se o meio técnico-cientifico-informacional sendo uma tendência hegemônica sobre o espaço geográfico, o qual, num contexto de globalização, imprime um novo tempo e modernização, além de exprimir novas técnicas e tendências. Santos (1994) ainda propõe que esse meio implante, tanto no campo como na cidade, as produções materiais e imateriais características da época, ou seja, direcionando sempre ao novo e moderno.

O processo de modernização, movimento que, inserido no meio técnicocientífico-informacional possibilitou a introdução de técnicas avançadas no campo através da incorporação de ciência, tecnologia e informação no processo produtivo, tem suas raízes no pós Segunda Guerra e na difusão do modelo da Revolução Verde, sendo esse, um conjunto de tecnologias que foram inseridas no mundo agrícola, também responsável pela criação e desenvolvimento de diversos insumos e maquinários que não existiam anteriormente ou dotados de alto grau tecnológico. Essa "revolução" se dá inicialmente nos países da América do Norte e, posteriormente, nos outros países, no globo, e por fim, tendo o nosso país como um dos protagonistas

O atual panorama do capitalismo no campo brasileiro está intrinsecamente ligado aos processos ocorridos no período da Revolução Verde no país, o qual acabou levando a produção no campo a uma condição de subordinação em relação à indústria e ao modo de produção capitalista. Tudo isso através de um processo de internalização da atividade 
agrícola, que tinha como pano de fundo os rumos intencionados por alguns países de capitalismo avançado.

Os principais pilares dessa modernização e estreitamento de setores evidenciam seu caráter conservador e doloroso, como destacado por Graziano da Silva (1980). Conservador porque mantém as relações econômicas e a estrutura fundiária que a precedeu, e doloroso pois relega uma condição de vida subalterna a uma parte significativa da população do campo

Como enfatizou Graziano da Silva (1980), os reflexos dessa modernização e da chegada dessas indústrias e tecnologias ao espaço rural tiveram fortes impactos na população, esse momento proporcionou a substituição da mão de obra, em que maquinário substituía o indivíduo que estava ali presente.

Desdobramentos dessas transformações são a saída do trabalhador do campo em direção às cidades, migração conhecida como êxodo rural, que possui caráter permanente e sendo motivada, principalmente, por motivo econômico, juntamente com a década de 30, período de urbanização e industrialização do Brasil, essa era de modernização levou diversas famílias para as cidades devido à falta de oportunidades no espaço rural.

Continuando as reflexões sobre esse momento, ao assumir, gradativamente, o comando da produção agrícola em diversos setores, a indústria capitalista conservou (e agravou) a extrema concentração de terras do Brasil. Alguns dos benefícios econômicos se vinculam ao aumento da oferta de matéria prima e à conexão com circuito global da economia.

Portanto, por conta da infinidade de produtos químicos e tecnologia empregada, a produção por hectares aumentou, rompeu barreiras naturais que impossibilitaram o crescimento produtivo e transformou de vez os sistemas agrícolas. Desde então, a agricultura se globalizou, recebendo produtos da indústria, como inseticidas, fertilizantes, maquinários e outros - como citado anteriormente - e, aumentando a oferta de matériaprima. $\mathrm{O}$ combate às pragas, a correção dos solos e o uso de máquinas como tratores e colheitadeiras, garantiram o lucro dos grandes capitais "dentro e fora da porteira".

Grandes animadores das cadeias de grãos e carne, as agriculturas do tipo empresarial desenvolvem formas de produção em que o assalariamento é predominante, as atividades são especializadas, a tomada de decisão é separada do ato produtivo e o aporte do capital é frequentemente externo. Em função da natureza padronizada da sua 
produção e dos grandes volumes envolvidos, elas são um dos elos fundamentais do agronegócio (BUHLER; GUIBERT; OLIVEIRA, 2016, p. 7).

Com o pretexto de que faltariam alimentos caso não houvesse uma mudança drástica na forma de produzir e a elevação da produção sendo possível apenas com o uso dos produtos vindos da indústria, a Revolução Verde acabou por introduzir pacotes que tirariam a necessidade do produtor de se adequar ao ritmo da natureza, podendo fazer uso de técnicas e produtos que relegassem as condições naturais em segundo plano no processo, logo, passou a exigir uma mão-de-obra cada vez menor e garantir matéria-prima em abundância após a colheita.

Nesse momento, a agricultura passou a ter as funções de suprir a crescente industrialização, com os recursos necessários à sua instalação, e de alimentar a crescente população urbana. Ela deixa de ser voltada exclusivamente para o mercado externo e passa a contribuir de forma mais significativa para o mercado interno. Para promover o aumento da produção e da produtividade agrícola, a partir de meados da década de 1960, o Estado, por meio de suas instituições de pesquisa e em cooperação com empresas multinacionais, reestruturou, mesmo que de forma seletiva, o sistema técnico agrícola brasileiro, por meio da implantação do paradigma da Revolução Verde. Este foi proposto e implementado por vetores externos como instituições dos EUA e multilaterais. (FREDERICO, 2010, p. 31).

As mudanças advindas dessa transição trouxeram a necessidade de implantação de uma indústria pesada no país, como a de maquinários e insumos, que abasteceria a agricultura de forma a modernizar os processos produtivos. A difusão de tecnologia e informação nos processos produtivos foi, continuamente, transformando a agricultura nacional. Com o passar dos anos, denotou-se a difusão do que se convencionou chamar de meio técnico-científico-informacional no campo brasileiro.

Esse processo denota, portanto

[...] a difusão do meio técnico científico no campo brasileiro, por meio da disseminação do pacote tecnológico da Revolução Verde, da mecanização da agricultura, da internalização da indústria de insumos agrícolas, do financiamento estatal e da especialização do trabalhador agrícola. (FREDERICO, 2010, p. 32). 
Diante da discussão realizada e da caracterização da época apresentada, a qual tem como marca a modernização e chegada das tecnologias ao espaço agrário, exposta acima como meio técnico-científico-informacional, devemos elencar dois pontos fundamentais para compreensão da pesquisa. Com a modernização do campo e estreitamento com o setor industrial, novas técnicas de correção de solos se tornaram presentes através dos insumos agrícolas e pesquisas. Como consequência - e marca da época - houve uma ascensão de novas terras agricultáveis, antes de produção inviáveis, conhecidas também como fronteira agrícolas, destas, o conhecido Cerrado se tornou protagonista, agora, com uma terra "corrigida" e lucrativa. Outro ponto fundamental desse texto é a utilização de geotecnologias, ponto que será discutido posteriormente.

\section{Geotecnologias e seus conceitos}

O principal conceito de Geotecnologias utilizado nesta pesquisa foi criado por Rosa (2005), que descreve as definições, composições e as diferentes tecnologias abarcadas de forma sucinta e específica em,

Também conhecidas como "geoprocessamento", as geotecnologias são o conjunto de tecnologias para coleta, processamento, análise e oferta de informações com referência geográfica. As geotecnologias são compostas por soluções em hardware, software e peopleware que juntos constituem poderosas ferramentas para tomada de decisões. Dentre as geotecnologias podemos destacar: sistemas de informação geográfica, cartografia digital, sensoriamento remoto, sistema de posicionamento global e a topografia (ROSA, 2005, p. 81). (grifo do autor).

É muito interessante notar o tamanho do conjunto tecnológico que engloba as Geotecnologias e as funcionalidades que possuem, podendo prover diferentes tipos de ações para diferentes tipos de casos e necessidades, com uma ampla gama de ferramentas, todas baseadas no principal, o banco de dados geográficos. Por outro lado, a EMBRAPA apresenta uma outra definição às Geotecnologias e demonstra as suas várias aplicações, dizendo que,

São conjuntos de técnicas e métodos científicos aplicados à análise, à exploração, ao estudo e à conservação dos recursos naturais, considerando diferentes escalas e a informação espacial (localização geográfica). As geotecnologias também são usadas para estudar a 
paisagem (topografia, hidrografia, geologia e geomorfologia) e variáveis ambientais (temperatura, pluviosidade e radiação solar), analisar e auxiliar na prevenção de desastres naturais (enchentes, terremotos e erupções vulcânicas), além de gerenciar e de monitorar a atividade humana (infraestrutura, agropecuária e dados socioeconômicos).

Esse conjunto de técnicas é composto por hardware (satélites, câmeras, GPS, computadores) e software capaz de armazenar, manipular informações geográficas e processar imagens digitais. (EMBRAPA, 2014, p. 34).

Acrescentando mais ideias à discussão, por uma outra interpretação, essas Geotecnologias também são comparadas ao Geoprocessamento e vinculadas à área da Geoinformação, como diz Presente, apresentando sua versão sobre o tema e apontando que,

\begin{abstract}
A Geotecnologia também conhecida por Geoprocessamento são conjuntos de técnicas que são coletadas, processadas analisadas e colocadas à disposição com referência geográfica. As Geotecnologias podem ser uma ferramenta poderosa para as tomadas de decisões, podendo ainda ser utilizada em diversas áreas, como a gestão ambiental, municipal e é claro na educação.

A Geotecnologia está ligada à área das geoinformações, que, no entanto é a aquisição de materiais que farão parte de análise ou processamento que nesta área é chamada de informações georreferenciadas, a Geotecnologia é o conceito dado aos estudos com as tecnologias de informação, ela é utilizada pela geografia, cartografia, topografia entre outras fontes do estudo geográfico. (PREZENTE, 2011, s/p).
\end{abstract}

Entender o conceito deste tema através da visão de diferentes autores, ajuda na assimilação de informações sobre a natureza e essência das Geotecnologias, além de facilitar o desenvolvimento da pesquisa, com foco em analisar o papel das Geotecnologias nas atividades agropecuárias.

\title{
A aplicação das Geotecnologias na agricultura
}

Logo a seguir, está destacado um trecho de uma publicação da EMPRABA (2014, p. 136), sobre as várias aplicabilidades das Geotecnologias na agropecuária que soma um total de 10 serviços feitos pelas ferramentas geotecnológicas, das quais é dito que,

As geotecnologias contribuem em diversos aspectos do cotidiano do agricultor e da agricultura. Como exemplo, podem-se destacar: 
- O mapeamento de propriedades rurais.

- O mapeamento de culturas, solo e relevo das áreas agrícolas.

- A certificação de imóveis rurais por meio do georreferenciamento usando-se sistemas de posicionamento global por satélite.

- A localização e a quantificação das áreas de preservação permanente e reserva legal dentro da propriedade.

- A adequação ambiental da propriedade frente ao código florestal brasileiro.

- O apoio aos processos de financiamentos rurais por meio de zoneamentos de riscos climáticos.

- A gestão da propriedade com a agricultura de precisão.

- Análises da dinâmica de uso da terra.

- A ocupação do território vinculado à atividade rural.

- Apoio ao desenvolvimento de política públicas por meio da compreensão de processos como expansão, retração, transição e intensificação da agricultura.

Visto essas aplicações e colocações da EMBRAPA, é essencial compreender como o financiamento e o incentivo nacional andaram, concomitantemente, com a modernização do campo, ou seja, como o Governo nacional foi responsável por incentivar, auxiliar e até mesmo financiar para que o campo brasileiro se "desenvolvesse". Um exemplo dessa parceria foi a criação da EMPRABA, citada anteriormente, na década de 1970, sendo ela a Empresa Brasileira de Pesquisa Agropecuária, ou seja, através do capital nacional, o desenvolvimento de pesquisas para a evolução da agropecuária no Brasil. A entidade se fortalece e debate importantes temas a cada ano.

No contexto das Geotecnologias, percebe-se como a EMBRAPA, nos últimos anos, segue a tendência do mercado mundial do agronegócio e faz um intenso debate sobre as Geotecnologias, um exemplo disso, é o lançamento da $26^{a}$ Feira Internacional de Tecnologia Agrícola em Ação, segundo a EMBRAPA, nessa Feira Tecnológica será apresentado a plataforma AgroAPI, que vai ofertar informações e modelos gerados pela EMBRAPA, os quais poderão ser utilizados por empresas e startups para a criação de softwares, sistemas web e aplicativos móveis.

Isso é a prova de como, no campo brasileiro, os investimentos nacionais e internacionais caminham paralelamente, e o agronegócio, desde seu fortalecimento no país, é tratado com bastante carinho pelos governantes, diferentemente de tantas outras instituições e grupos. Ainda assim, os investimentos governamentais no setor necessitam de um direcionamento específico aos pequenos produtores, com o fito de ajudar na inserção deste tipo de tecnologia na produção de menor escala. 
Continuando este assunto e trazendo outras contribuições pertinentes ao tema, devemos considerar como as Geotecnologias servem, atualmente, como importante suporte para a agricultura de precisão,

As geotecnologias, definidas aqui como o conjunto de métodos e técnicas para aquisição, modelagem e análise de dados geoespaciais, por vezes obtidos através de sensoriamento remoto insere-se como suporte fundamental para a Agricultura de Precisão, seja no seu aspecto tradicional de acompanhamento da propriedade, no município ou no âmbito regional, reiterando a necessidade do mapeamento e monitoramento multiescala. (GREGO et al, 2014, p. 448).

Dentro das novas tecnologias propostas com a chegada do meio técnico-científicoinformacional, citadas anteriormente por Grego, devemos discutir sobre as características e complexidades da agricultura de precisão, sendo ela um conjunto de tecnologias ligadas ao setor primário, no qual ocorre o cultivo e a produção ligada às conjunturas informacionais. Essa técnica utiliza uma aparelhagem no campo para acompanhar as diversas variáveis com intuito de diminuir riscos, aumentar a produtividade, dentre outros fatores. Ao observar a figura 01, notam-se essas variáveis, destrinchadas em diferentes zonas agrícolas do país.

Figura 01: Razões para o uso de técnicas e tecnologias de Agricultura de Precisão

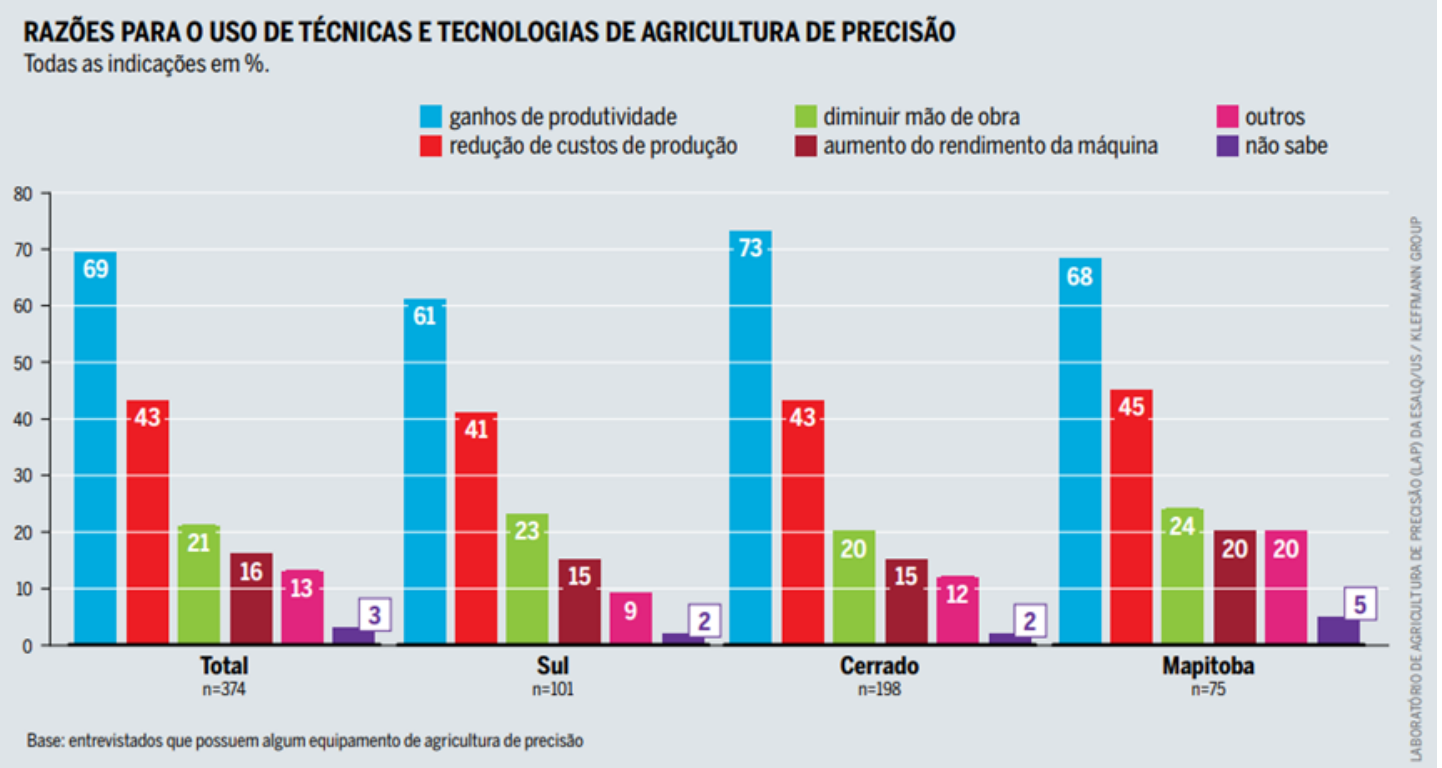

Fonte: Atlas do Agronegócio 2018. 
Como mostrado na imagem, percebe-se o Cerrado brasileiro evidenciado ao lado de outras regiões do Brasil, sendo a área de estudo da pesquisa, a microrregião de Ituiutaba, inserida no diagrama analisado. No gráfico, são colocados diversos motivos os quais se utiliza a agricultura de precisão, sendo, em todas as regiões, o fator "ganho da produtividade" o primordial. Isso apenas reafirma, cada vez mais, como essa agricultura moderna está diretamente ligada ao ganho do capital, ao lucro, reflexo do neoliberalismo e do meio técnico-científico-informacional enraizado no campo.

Outro fator observado na figura é como, para certos agricultores, a razão para o uso de geotecnologias é a diminuição da mão de obra, ou seja, a substituição do homem pelo maquinário, situação que ocorre, gradativamente, desde o processo de modernização no campo nas décadas de 60 e 70 e se reafirma na atualidade com o meio técnicocientífico-informacional, nesse caso, por meio das Geotecnologias. Dentre as diversas consequências da mecanização da mão de obra está o êxodo rural e, consequentemente, a diminuição da população rural do país.

Ainda sobre a Agricultura de Precisão, a técnica promete "revolucionar" as áreas de produção, ou seja, a prova de como o capitalismo e seus modelos de produção se reinventam e se desdobram, a fim de ampliar os ganhos e aperfeiçoar o tempo. Segundo o Atlas do Agronegócio de 2018, o artigo "Manobras Digitais - Quando os tratores funcionam online" nos mostra como essa agricultura de precisão está ligada ao termo "tecnologia agrícola" ou "Agrotecnologia", sendo um forte ramo do agronegócio o qual emergiu com a Revolução Científica e que, só no ano de 2013, teve um faturamento de 137 bilhões de dólares americanos. Dentro dessa tecnologia agrícola, está inserida a produção de maquinários que estão em todos os processos de produção no campo, além do investimento de Geotecnologias e Agricultura de Precisão, um mercado que vem criando espaço a cada ano.

Por outro lado, as Geotecnologias não são utilizadas somente como suporte ao desempenho da agricultura de precisão, mas também da pecuária de precisão, através de ferramentas fornecidas como o Sensoriamento Remoto e o SIG,

A utilização do sensoriamento remoto, aliado aos sistemas de informação geográfica, desempenha um papel fundamental na organização do espaço. Dependendo do banco de dados amarrado a um mapeamento existente e imagens de satélites, podem-se fazer os mais 
diversos estudos inerentes às atividades da pecuária. (AMARAL et al, 2016, p. 20).

Como apresentado, percebe-se cada vez mais a utilização de aparelhos de GPS e SIG no campo brasileiro, muitas vezes, presentes nos maquinários atuais. Segundo o Atlas do Agronegócio, grandes exemplos dessa relação são os tratores com guiamento automático por GPS, além de drones que controlam a pulverização de agrotóxicos e fazem o monitoramento das lavouras, chamados de robôs agrícolas, ou seja, a mecanização cada vez mais profunda e complexa.

Continuando com as suas contribuições, estes autores apresentam como é realizado o monitoramento das atividades pastoris através de rastreamento do rebanho por GPS, ademais, para frisar a importância do controle de todas as fases de produção através da "georrastreabilidade",

\begin{abstract}
A utilização de sistemas de Informação Geográfica (SIG) para interpretação e qualificação das pastagens e de GPS em animais possibilita a obtenção de informações georreferenciadas para entendimento da distribuição e do deslocamento espacial desses animais e monitoramento de suas atividades como pastejo, trajeto, descanso e ruminação em função da oferta e da preferência da dieta oferecida nas pastagens. Através do controle de todas as fases de produção, industrialização, transporte, distribuição e comercialização, a georrastreabilidade agrega qualidade ao produto, permitindo assegurar a origem e o manejo feito desde o campo até o prato do consumidor. (AMARAL et al, 2016, p. 21).
\end{abstract}

Assim, dentre as inúmeras aplicabilidades das Geotecnologias, esta investigação primou pelas voltadas às questões agropecuárias, por levar em consideração a aptidão do recorte espacial selecionado.

\title{
O campo moderno na Microrregião Geográfica de Ituiutaba
}

Como discutido anteriormente, a inserção do meio técnico-científicoinformacional foi responsável por uma série de mudanças no Espaço agrário brasileiro, ocorrendo uma série de inovações tecnológicas ligadas à indústria, além de manter as características de concentração fundiária do seu passado histórico. Na mesorregião do Triângulo Mineiro não foi diferente, ela representava uma grande área de expansão da 
fronteira agrícola rumo à região Centro-Oeste da nação, cujas barreiras químicas - no caso, um solo de Cerrado ácido - havia sido superada com a Revolução Verde e suas táticas de correção do solo. Esse período de expansão agrícola é descrito por Pereira a seguir, no qual ele diz que,

Particularmente no que se refere à moderna agropecuária e as investidas do Estado brasileiro para sua expansão nos anos 1960/1970, este processo homogeneizador atinge regiões como o Triângulo Mineiro, além de uma série de outros fronts que se estabeleceram principalmente em Goiás e Mato Grosso, dissolvendo relações estabelecidas historicamente e que passam a ser consideradas "arcaicas", o que no Triângulo Mineiro significa um processo de inserção e aprofundamento de relações capitalistas de produção que envolvem, entre outros aspectos, a titulação e venda de terras (acompanhada de sua valorização) as relações assalariadas de trabalho no campo (redefinindo as condições de produção tradicional), e a inserção de novas condições gerais de produção que viabilizam a moderna agropecuária (infraestrutura de escoamento e armazenamento etc.) (PEREIRA, 2015, p. 71).

As transformações foram diversas e seus desdobramentos se deram de forma complexa e, em vista de todas essas dinâmicas, chegamos em nossa área de estudo, a microrregião de Ituiutaba que, como dito anteriormente, se faz presente dentro do Triângulo Mineiro e participou da chegada e enraizamento do meio técnico-científicoinformacional, possibilitando o cultivo de áreas que antes não possuíam produtividade e, consequentemente, valorização.

Novas terras foram aderidas à agricultura ao longo dos anos, isso se deu por vários fatores, como a possibilidade de cultivo em áreas de solos improdutivos ou que possuíam relevo impróprio para produção. As novas tecnologias, como a utilização de maquinário mais eficiente, bem como a correção dos solos, foram fundamentais para esse aumento significativo. Devemos considerar também as áreas desmatadas e que ainda sofrem esse processo nos dias de hoje, uma terra que outrora já era valorizada, hoje, com seu protagonismo comercial, sofre a cada hectare.

Na microrregião, o processo de utilização de Geotecnologias e agricultura de precisão também se faz presente, dentro da agricultura moderna, torna-se uma das regiões mais expressivas na produção, com destaque no cenário nacional. A seguir, podemos observar o gráfico 01 de área plantada com os principais cultivos da área. 
Gráfico 01: Área Plantada (hec.) Cana, Soja e Milho na Microrregião de Ituiutaba

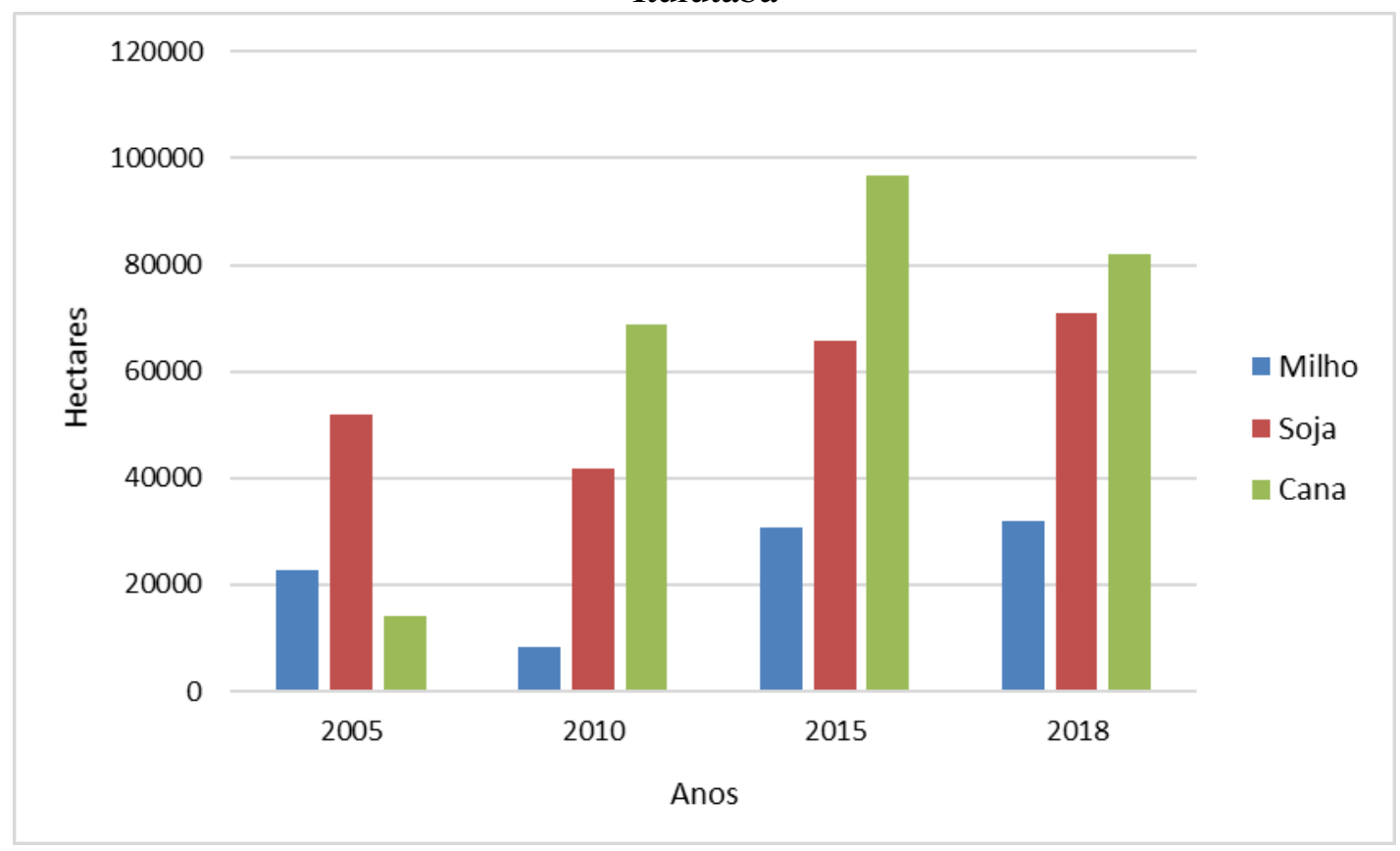

Fonte: PAM/IBGE, 2020.

Org.: Autores, 2020.

Ao analisar o gráfico 01, percebe-se grande quantidade de áreas plantadas e, observa-se também uma tendência de aumento gradativo dessas áreas com o decorrer dos anos, assim, com as tecnologias, se deve cada vez mais ocorrer melhorias e a práticas de correção dos solos, o qual antes era considerado infértil ou de produção ruim, atualmente já não se mostra uma grande barreira. Observa-se também no gráfico, a ascensão da canade-açúcar na região, tendência que se iniciou fortemente no estado de São Paulo e hoje se faz presente na região estudada.

\section{A presença das Geotecnologias na Microrregião de Ituiutaba}

Nesta parte do trabalho, foram apresentados os resultados encontrados com a investigação realizada, principalmente, através de reambulação em campo. Contudo, antes de começar a discorrer sobre as informações apuradas, faz-se necessário explicar de quais formas ocorreram as reambulações em campo e os seus objetivos para este trabalho.

A primeira reambulação em campo teve como foco se deslocar em locais pontuais para consultar algumas empresas que atuam no ramo de suporte e consultoria às 
atividades agropecuárias, buscando conhecer o tipo de serviço prestado aos produtores rurais que utilizam ferramentas de Geotecnologias.

Já a segunda reambulação em campo foi mais ampla com prioridade em percorrer a zona rural de todos os municípios da Microrregião Geográfica de Ituiutaba para coletar informações referentes ao uso de Geotecnologias como suporte à produção de qualquer atividade agropecuária existente neste recorte espacial e, para isso, caberiam visitas às propriedades rurais, agroindústrias, sindicatos de produtores rurais e à EMATER-MG Empresa de Assistência Técnica e Extensão Rural do Estado de Minas Gerais.

Vale ressaltar que todas as informações coletadas nas reambulações em campo foram registradas visualmente e/ou fotograficamente no local ou esclarecidas por meio de conversas informais com funcionários de empresas, agroindústrias, sindicatos, EMATER-MG ou pelos próprios produtores.

Através da primeira reambulação em campo, foram coletadas informações referentes a cinco empresas do ramo de Agrimensura, Topografia e Consultoria Ambiental que estão localizadas em alguns municípios da microrregião estudada, conforme é apresentado no esquema do quadro 01. No total são cinco empresas, das quais uma fica em Capinópolis, uma em Santa Vitória e três em Ituiutaba.

Quadro 01 - Distribuição de empresas que atuam com agrimensura e topografia na MRG de Ituiutaba/MG em 2018.

\begin{tabular}{|l|l|}
\hline Municípios & \multicolumn{2}{|c|}{ Empresas } \\
\hline Capinópolis & Geocap Agrimensura e Topografia ltda. \\
\hline Ituiutaba & $\begin{array}{l}\text { Integral Topografia; Agritec-Agrimensura e Tecnologia; } \\
\text { CAMPOSAT. }\end{array}$ \\
\hline Santa Vitória & Capop Agrimensura. \\
\hline \multicolumn{1}{c}{ Fonte: Pesquisa de Campo, 2018. } \\
& Org.: Autores, 2018.
\end{tabular}

De acordo com a apuração feita através das empresas consultadas na primeira reambulação em campo, foi relatado que produtores rurais dos municípios de dentro e fora da microrregião, solicitam a prestação de serviços para auxiliar na organização e funcionamento de determinadas atividades agropecuárias. Dentre os serviços, os mais empregados são o georreferenciamento para delimitação das áreas de plantio e/ou de pastagem, e das propriedades rurais, além do levantamento topográfico do terreno e, até mesmo, mapeamento. Todos esses serviços prestados aos produtores utilizam 
Geotecnologias e, entre elas, a mais utilizada, segundo informado, é o GPS de precisão que garante coordenadas precisas de determinado ponto na superfície terrestre.

Após finalizar as pesquisas da primeira visita ao campo, iniciou-se a segunda, percorrendo todos os municípios da MRG de Ituiutaba, com o intuito de verificar a utilização de Geotecnologias nas atividades produtivas do meio rural da região.

A segunda fase no campo teve início no município de Santa Vitória, o mais extenso territorialmente da região, onde foi registrado a existência majoritária de plantios de cana-de-açúcar entre as demais atividades agropecuárias existentes. Isso corrobora com os dados fornecidos pelo IBGE (2019), que apontavam Santa Vitória como o município com maior índice de produção de cana-de-açúcar da microrregião em 2017.

A existência de tantas lavouras de cana-de-açúcar se deve à presença de duas usinas sucroenergéticas no município, que não apenas incentivaram como também implementaram a expansão desta cultura no município, pois essas usinas são as proprietárias de quase todas as plantações de cana, que se espalham para além dos limites do município de Santa Vitória. Segundo a apuração, a usina dispõe de grandes recursos financeiros e utiliza uma parte em alta tecnificação para cuidados com as lavouras.

Figura 02 - Vista parcial de extensa monocultura de cana-de-açúcar em Santa Vitória/MG.

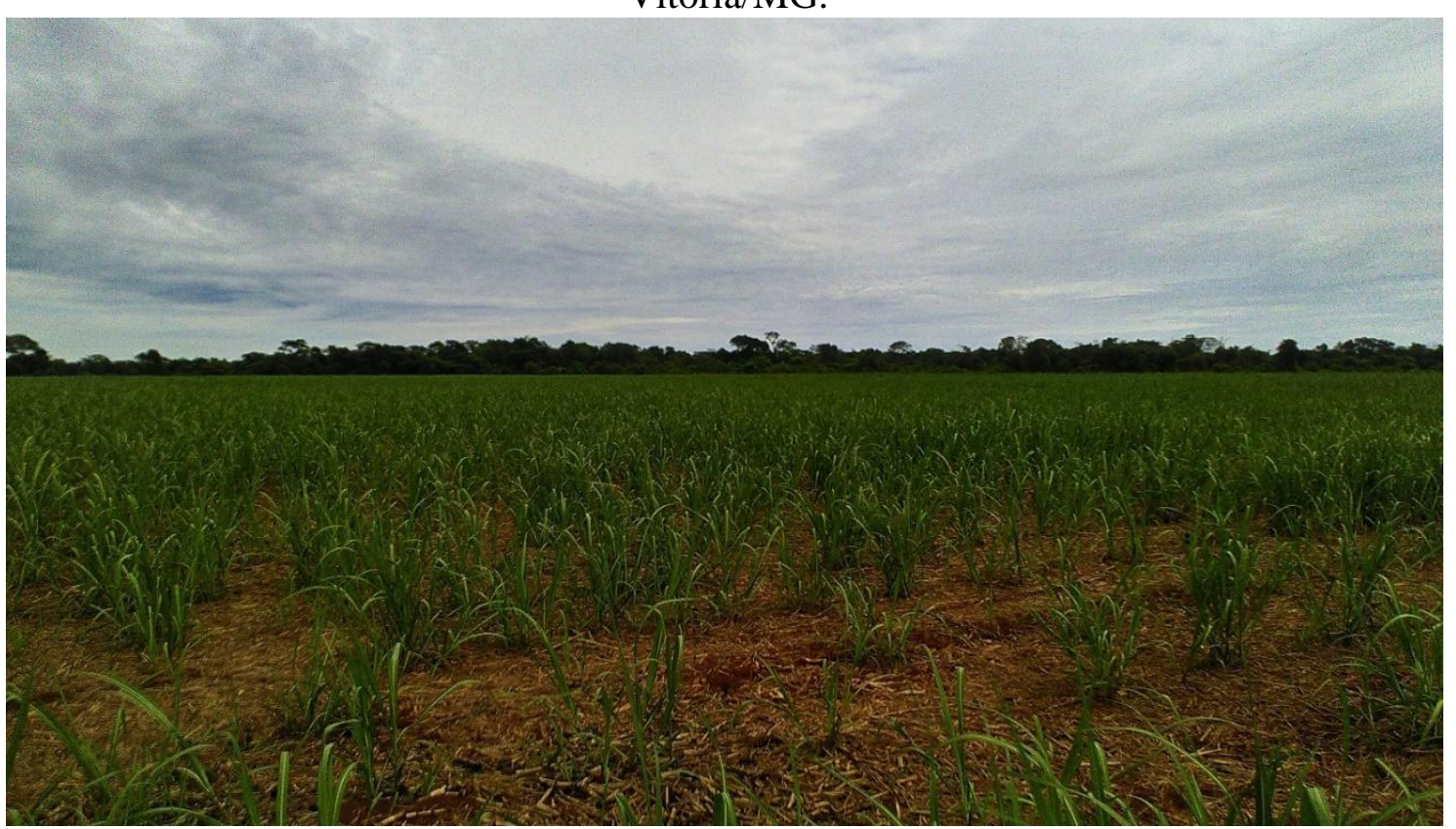

Fonte: Pesquisa de Campo, Nov. 2018. 
Os relatos fornecidos por funcionários das usinas confirmam que, dentre os investimentos feitos para alta tecnificação no campo, consta a utilização de maquinários agrícolas guiados por GPS. Essa informação em si demonstra que, nas atividades rurais, além de existir a possibilidade de solicitar uma prestação de serviço de empresas que atuam com Geotecnologias, também existe a opção dos próprios produtores investirem nessas tecnologias por conta própria, pelo menos nas plantações de cana-de-açúcar das usinas de Santa Vitória, como a lavoura na figura 02.

Não houve relatos e nem registros que confirmem a utilização de Geotecnologias em outros cultivos ou em criações de animais no município.

O seguinte município a ser pesquisado na reambulação foi Gurinhatã, que apresentava na paisagem, majoritariamente, cultivos de cana-de-açúcar e pastagem para rebanhos bovinos. Vale ressaltar que as culturas de cana neste município também são de propriedade das usinas sucroenergéticas dos municípios vizinhos, Santa Vitória e Ituiutaba.

De acordo com o que já havia sido informado sobre as usinas de Santa Vitória, estas empresas utilizam maquinários guiados por GPS em todas as lavouras de cana para os devidos tratos culturais e isso inclui as lavouras existentes nos municípios vizinhos, como Gurinhatã. Com este relato, pode-se dizer que existe utilização de Geotecnologias nas plantações de cana-de-açúcar do município.

Além disso, buscamos saber se também existia utilização de Geotecnologias em outros cultivos ou em criações de animais, pois era fácil observar pelo município alguns locais de confinamento e áreas de pastagens para bovinos, como mostra na figura 03. Contudo, nenhum dos profissionais consultados soube informar se tais tecnologias estavam sendo implantadas em outras culturas que não fosse a cana-de-açúcar. 
Figura 03 - Vista parcial de criação de gado de corte em área de pastagem no município de Gurinhatã/MG.

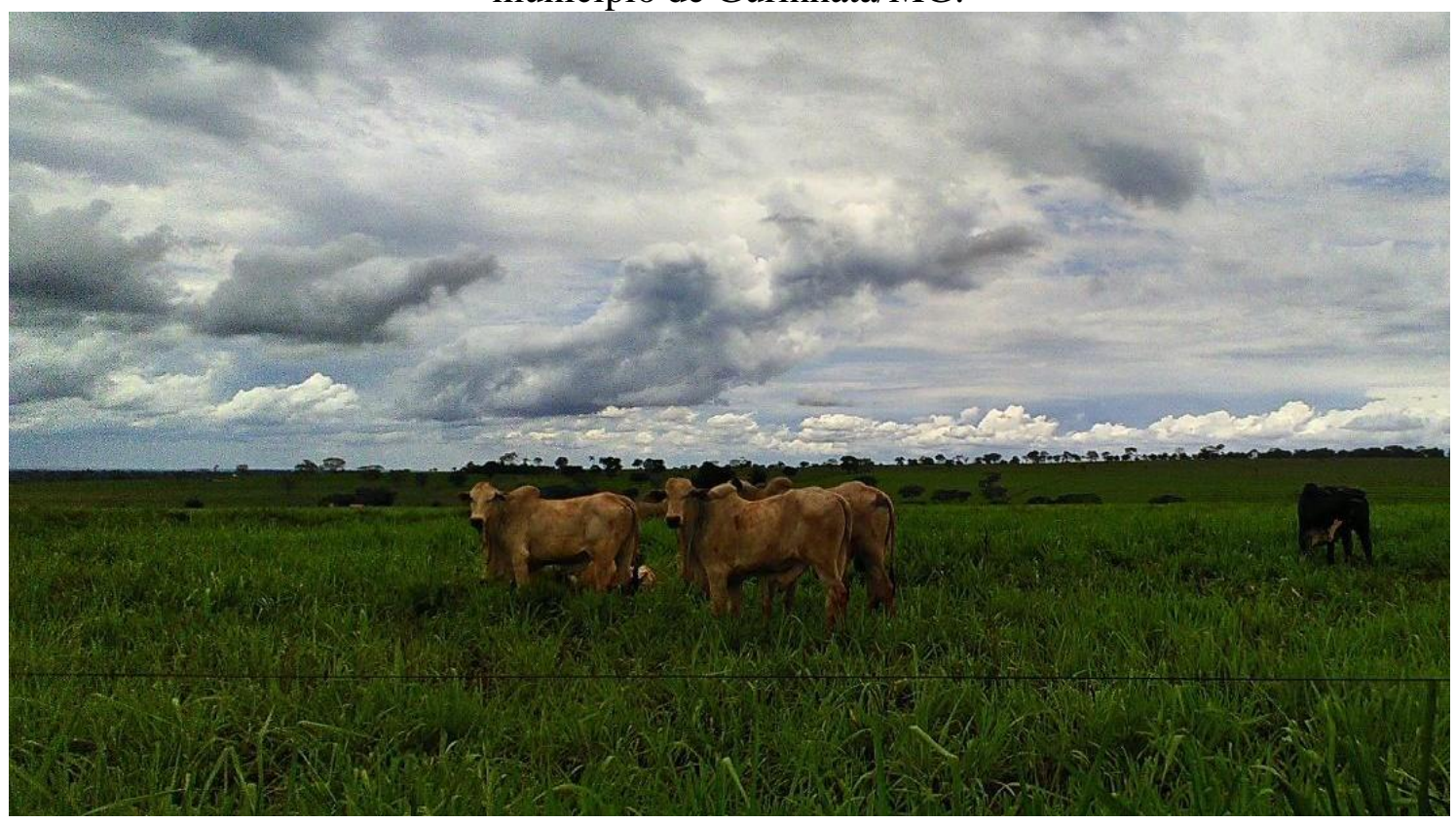

Fonte: Pesquisa de Campo, Nov. 2018.

Ainda sobre Gurinhatã, vale ressaltar que, de acordo com os profissionais consultados, houve a revelação de um certo desagrado com a forte presença dos cultivos de cana-de-açúcar trazidos pelas usinas. Foi deixado claro que este tipo de cultura não é benéfica para o desenvolvimento de Gurinhatã por não trazer real desenvolvimento ao campo, apenas degradação. Isso mostra uma certa preocupação dos profissionais rurais com a propagação deste tipo de monocultura.

Dando prosseguimento ao trabalho de campo, Ituiutaba foi o terceiro município a ser pesquisado durante a reambulação. Descrevendo o cenário agropecuário local, foi possível visualizar maior diversidade de culturas, se comparado ao que foi visto nos municípios anteriores. Entre as culturas mais diversificadas, observou-se a cultura de grãos, como milho, soja e sorgo, além de outros tipos de criações de animais, como granjas para galináceos e suínos. Claramente o cultivo de cana-de-açúcar e a criação de bovinos também eram muito notáveis, principalmente por conta da presença de uma usina sucroenergética em Ituiutaba, conforme já mencionado, e também, devido à presença de frigoríficos neste mesmo município, como informa Teixeira (2017).

O cultivo de cana-de-açúcar também é o mais relevante em Ituiutaba, contando com o segundo maior índice de produção em toneladas na microrregião, conforme o IBGE (2019). As lavouras de cana, propriedades da mencionada usina local, se estendem 
em boa parte do município em questão, e também, no município de Capinópolis, além de outros fora da microrregião segundo funcionários da própria usina.

Agora, abordando especificamente sobre o papel das Geotecnologias, foi confirmado que a usina de Ituiutaba utiliza várias dessas tecnologias nos cultivos de canade-açúcar de todas as suas plantações. Entre as Geotecnologias utilizadas constam maquinários guiados automaticamente por GPS, imagens de satélite, GPS de precisão e mapeamento por drones. Confirma-se então, o emprego de ferramentas geotecnológicas em atividades rurais no município de Ituiutaba, especificamente na produção de cana.

Figura 04 - Vista parcial de trator guiado por GPS efetuando tratos culturais em uma lavoura de cana-de-açúcar em Ituiutaba/MG.

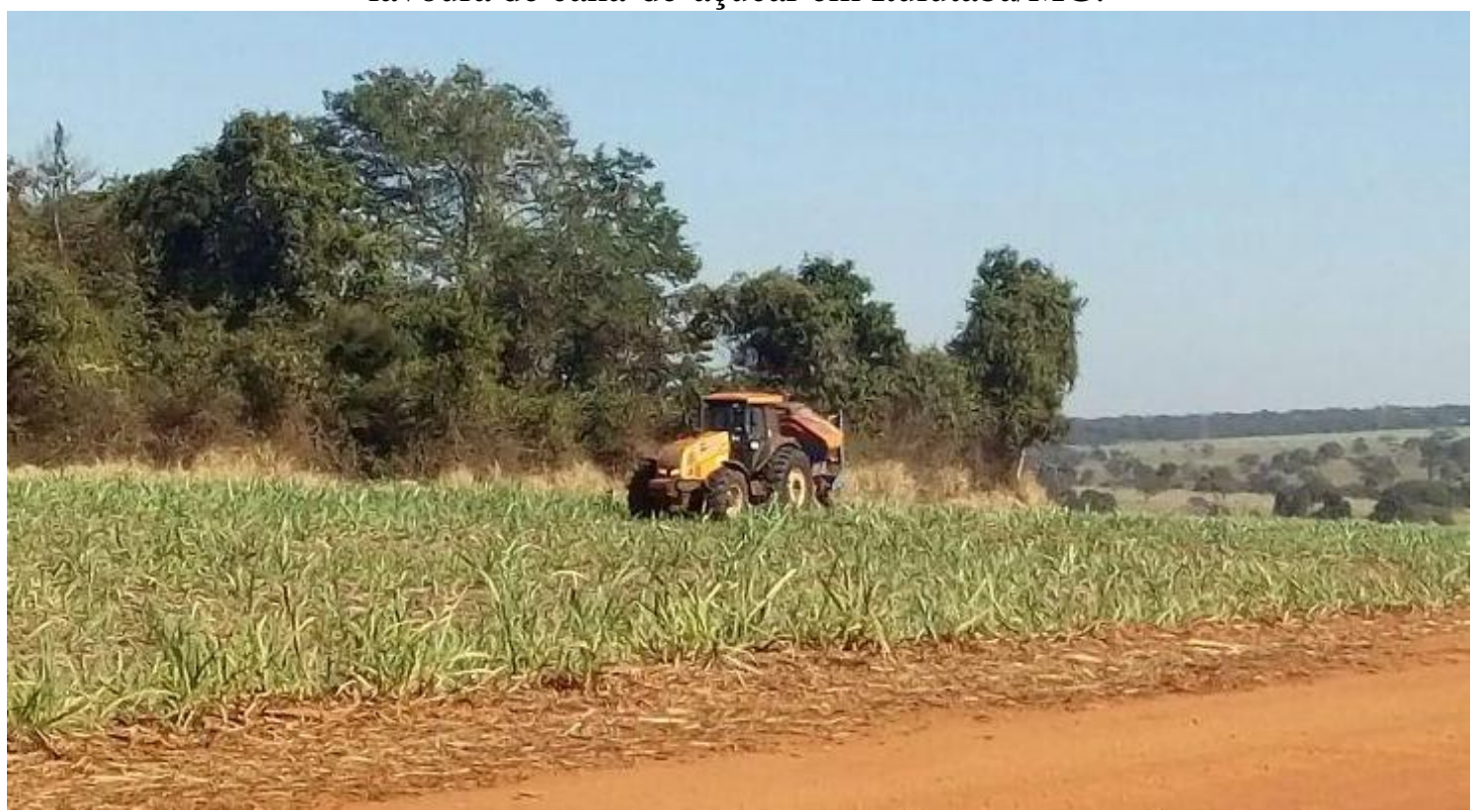

Fonte: Pesquisa de Campo, Nov. 2018.

Ainda em Ituiutaba, foi possível observar o funcionamento de uma máquina agrícola guiada por GPS que realizava tratos culturais em uma lavoura de cana-de-açúcar, conforme ilustra a figura 04.

Não obstante disso, foi confirmado que outros produtores no município também utilizam das Geotecnologias para auxiliar na produção de outros cultivos, como os de grãos já mencionados e, dentre os possíveis aparatos utilizados, constam maquinários agrícolas guiados por GPS.

Não foram encontradas informações que afirmassem o uso de Geotecnologias na criação de animais no município. 
O quarto município a ser pesquisado foi Ipiaçu, localizado mais ao norte da microrregião e sendo menor, territorialmente, que os três anteriores. Durante a reambulação em campo, observou-se vários cultivos de grãos como milho, soja e, principalmente, extensas lavouras de sorgo, como é ilustrado na figura 05. Também foram observadas áreas de bovinocultura durante o percurso pelo município.

Figura 05 - Vista parcial de extenso cultivo de sorgo em Ipiaçu/MG.

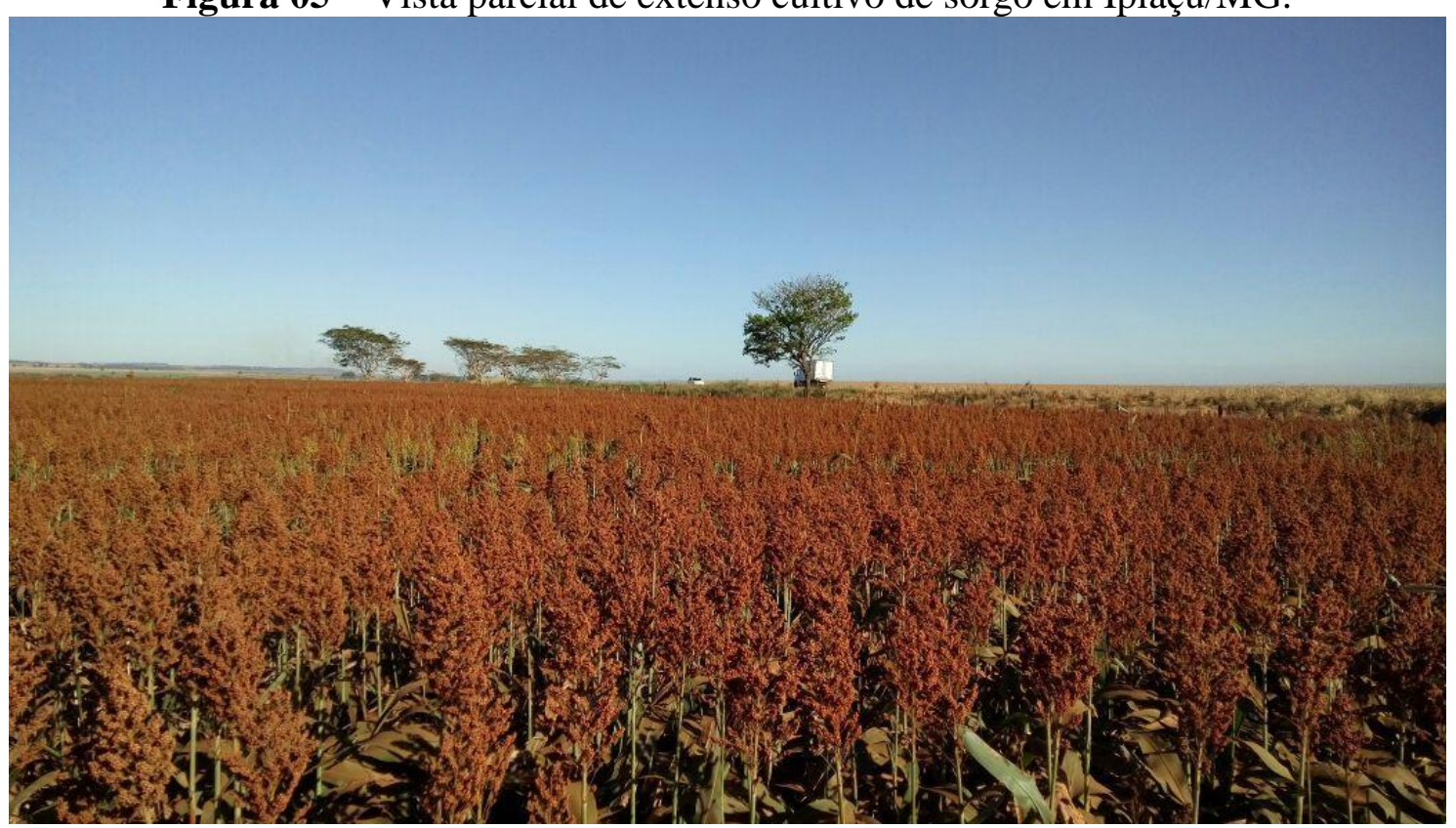

Fonte: Pesquisa de Campo, Jul. 2017.

Em relação às Geotecnologias, nenhuma das fontes consultadas pôde afirmar se existiam ou não o emprego deste tipo de aparato em atividades agropecuárias neste município. Ademais, não foi possível observar essas tecnologias sendo aplicadas ao vivo, como ocorreu em Ituiutaba.

Sem poder consultar outras fontes ou adentrar todas as propriedades rurais, não foi possível concluir se de fato as Geotecnologias já são ferramentas utilizadas pelos produtores em suas atividades agropecuárias ou não, sendo possivelmente cabível a necessidade de uma nova reambulação em campo que seja mais aprofundada no município em questão.

No extremo nordeste da MRG de Ituiutaba, encontra-se o menor município da microrregião, Cachoeira Dourada, que também apresenta a menor parcela produtiva dentre os outros municípios, mas, nem por isso é menos relevante. 
Um dado curioso sobre o município é que este é o único na microrregião que não apresentou índices de produção de cana-de-açúcar em 2017, segundo o IBGE (2019), despontando mais na produção de grãos.

Durante a reambulação em campo, realmente não foram avistadas quaisquer lavouras de cana, porém, na contramão, observou-se várias áreas de cultivo de milho e soja, alguns deles com sistemas de pivô central, além de terem sido notadas muitas áreas de pastagem para rebanhos de bovinos, inclusive pastagens cultivadas.

Figura 06 - Vista do alto de propriedade de criação de gado leiteiro e produção de leite em Cachoeira Dourada/MG.

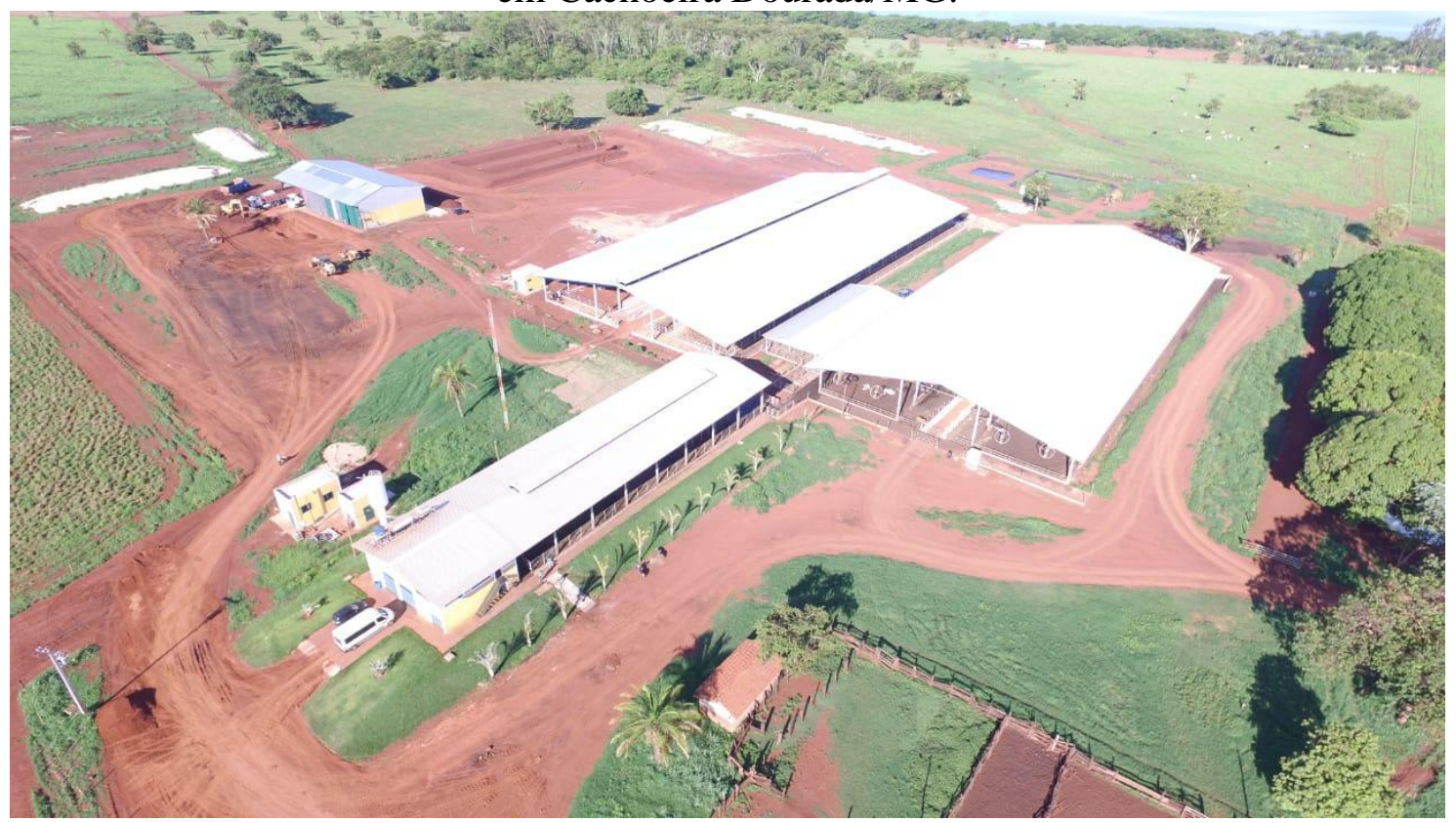

Fonte: Pesquisa de Campo, Nov. 2018.

Foram observados vários processos de plantio de soja pelo município, sendo notável um alto grau de tecnificação nessas atividades. No entanto, uma propriedade que trabalha com produção de leite, ilustrada na figura 06, foi a que mais chamou a atenção durante a reambulação. Através do que pôde ser apurado durante uma visita ao estabelecimento, foi descoberto que a propriedade possui um alto grau de tecnificação para os cuidados com os animais e para as coletas de leite.

Neste estabelecimento existia uma área de confinamento para a coleta de leite e uma área de pastagem para alimentação do gado. Como forma de abastecer o rebanho de bovinos com uma alimentação adequada, além da área de pastagem a propriedade também contava com sua própria lavoura de milho que, segundo informado, utilizavam tratores 
Aplicação de geotecnologias na agropecuária da microrregião geográfica de Ituiutaba/Minas Gerais
Roberto Barboza Castanho Victor Matheus da Cruz de Carvalho Guilherme Henrique dos Santos Santana

guiados por GPS para tratos culturais da plantação. Além disso, o estabelecimento estava em processo de compra de um drone para o mapeamento das lavouras, áreas de pastagem e monitoramento do rebanho.

Este foi o primeiro indício sólido de uso de Geotecnologias na criação de animais, mostrando que realmente existem investimentos sendo feitos com essas tecnologias em atividades pecuárias da microrregião. Segundo outras informações coletadas, as demais culturas de grãos existentes no município apresentam uso de Geotecnologias na forma de maquinários guiados por GPS e drones para mapeamento e monitoramento de lavouras.

Já o último município pesquisado foi Capinópolis que mostrou, de forma clara, assim como Cachoeira Dourada, possui tendência a manter o foco na produção de grãos. Vale endossar que este município foi um dos primeiros que introduziu o cultivo de soja na mesorregião do Triângulo Mineiro/Alto Paranaíba, de acordo com Cleps Jr.(1998) e, ressalta-se que a produção de cana-de-açúcar também é relevante neste município, devido à influência da usina sucroenergética em Ituiutaba, como já foi mencionado.

Em relação à produção de grãos, foi possível observar na figura 07 um dos muitos silos existentes neste município.

Figura 07 - Em primeiro plano, vista parcial para o cultivo de milho, e em segundo plano, silo utilizado no armazenamento da produção de grãos em Capinópolis/MG.

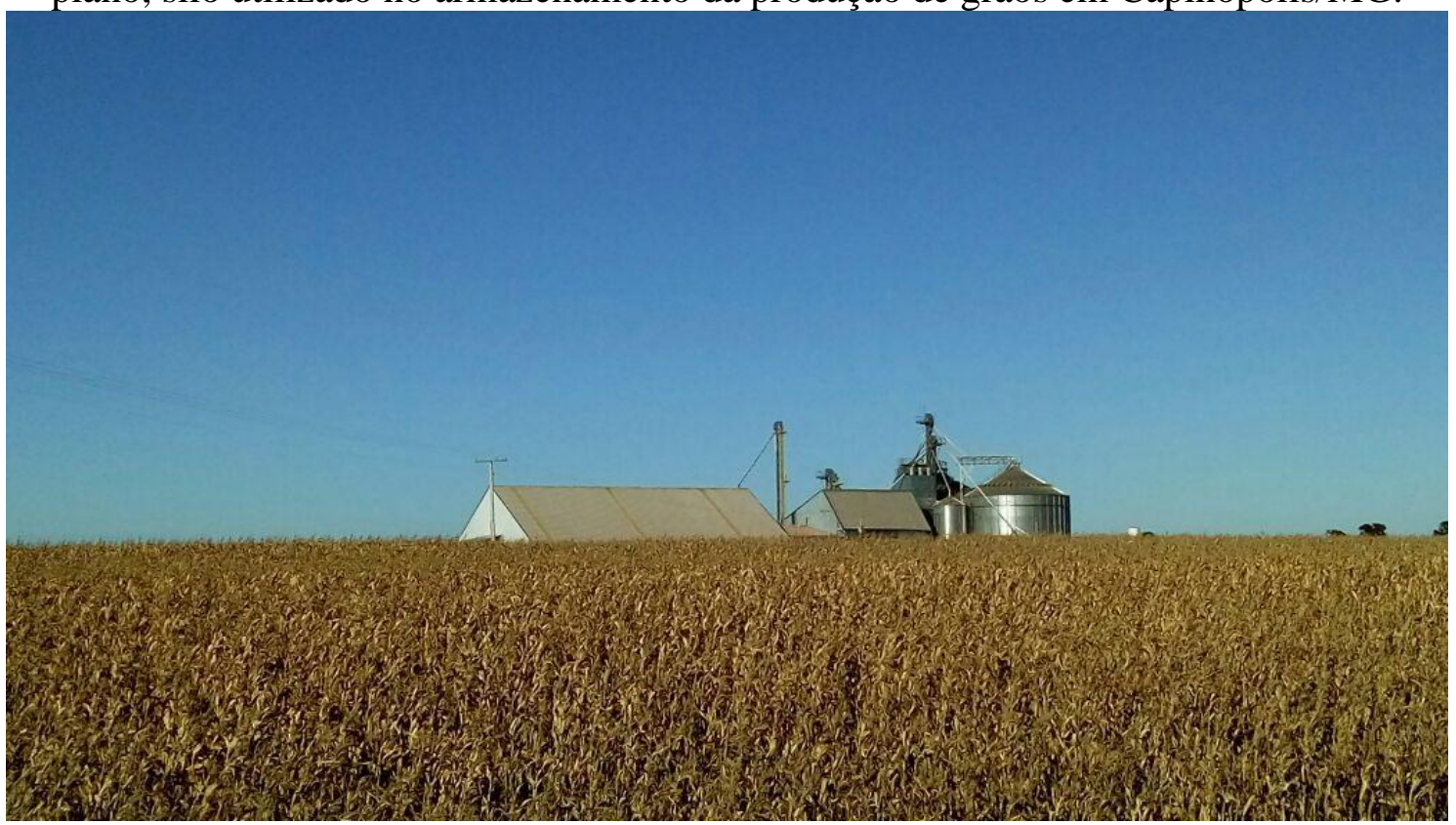

Fonte: Pesquisa de Campo, Jul. 2017. 
Também foram observadas muitas áreas de pastagem cultivadas para rebanhos de bovinos, principalmente de corte.

Segundo as informações coletadas durante a reambulação no campo, o município de Capinópolis possui muitos produtores de grãos que, por sua vez, investem recursos generosos na tecnificação e modernização das atividades agrícolas, especificamente, na produção de milho e soja. Entre os investimentos feitos está a adoção das ferramentas de Geotecnologias, seja em maquinários agrícolas guiados por GPS, ou através de imagens de satélite e até mesmo drones, tudo para aprimorar as capacidades de produção de grãos no município.

Sobre a pecuária em si, no município não foram coletadas informações que afirmassem a aplicação de Geotecnologias neste tipo de atividade.

Desta maneira, foi possível afirmar que em todos os municípios, com exceção de Ipiaçu, houve relatos e indícios de utilização de Geotecnologias na agricultura, embora somente em Cachoeira Dourada se obteve informações sobre o uso de Geotecnologias na criação de animais.

Sendo assim, as principais atividades agropecuárias que utilizam Geotecnologias na Microrregião de Ituiutaba, segundo a apuração, são, primeiramente, os plantios de cana-de-açúcar e, depois, os grãos milho, soja e sorgo, além do único registro de futuro uso na criação de gado leiteiro.

As Geotecnologias empregadas nas atividades rurais da microrregião apontaram diversas aplicabilidades e contribuições para os produtores. Pode-se citar as máquinas agrícolas guiadas por GPS, que aprimoram as atividades de plantio, tratos culturais e colheita; o GPS de precisão que fornece um preciso levantamento topográfico do terreno; o uso de imagens de satélites e de drones, estes por sua vez, aprimoraram as técnicas de monitoramento das lavouras e possuem capacidade de serem utilizados até mesmo para o monitoramento e rastreio de animais.

Finalizando, o emprego dessas Geotecnologias, segundo foi apontado pelos próprios produtores, contribuem para a melhor produtividade no campo e, consequentemente, ajudam a maximizar os lucros. $\mathrm{O}$ aumento de produtividade tem sido um dos principais motivos para o investimento do setor em tecnologias de ponta.

No entanto, é necessário ressaltar que os perfis dos produtores consultados nesta pesquisa mostram que os proprietários e empresas investidores das Geotecnologias 
possuem grandes recursos de capital para tal. Não foi identificado nenhum pequeno produtor que esteja utilizando Geotecnologias como recurso para incremento produtivo. Talvez por ser uma nova tecnologia com custo de aquisição e de operação elevado, seja necessário que instituições governamentais deem apoio e suporte aos pequenos produtores, a fim de incentivar a melhoria de seus sistemas produtivos e garantir melhores oportunidades de mercado que, atualmente, é dominado por grandes produtores e latifundiários.

\section{Considerações finais}

Pode-se dizer que estudar as características do meio rural é complexo pelo fato do Brasil ser um país gigantesco e apresentar tantas faces e peculiaridades em seu território. Mesmo diante dessas faces, a agropecuária moderna se mostra a grande protagonista no quesito econômico, dotada de várias artimanhas e tecnologias.

Destas tecnologias apresentadas no texto, pode-se elencar as Geotecnologias e a Agricultura de Precisão e as formas como elas estão inseridas na área de estudo da pesquisa, de maneira especial na agricultura moderna. Essas técnicas, juntamente com outros fatores, como por exemplo, investimentos maciços do capital estrangeiro, levam a Microrregião de Ituiutaba, como todo Cerrado Mineiro, à categoria de potência em produção agropecuária, com alto índice de modernização e produtividade.

Essas mudanças, como o caso do Cerrado, mostram como diversos agentes modificam o Espaço em que vivemos, visto as transformações que essa região sofreu ao passar das décadas, cada vez mais enraizado ao mundo globalizado e as tendências do meio técnico-científico-informacional, que impõem suas características e visa como principal pilar o lucro.

Constatou-se na pesquisa que vários produtores agropecuários já utilizavam dessas novas tecnologias, como por exemplo, nos plantios de cana-de-açúcar, de milho, de soja, dentre outros, sendo que o principal argumento dos produtores é a produtividade e o lucro, como dito anteriormente, pilares do sistema vigente. Vale ressaltar que, no entanto, os produtores que têm acesso a este tipo de tecnologia possuem alto poder aquisitivo, não tendo sido encontrados pequenos produtores com possibilidade de investimento em tais tecnologias, sendo necessário maior apoio governamental para tal. 
Aplicação de geotecnologias na agropecuária da microrregião geográfica de Ituiutaba/Minas Gerais
Roberto Barboza Castanho Victor Matheus da Cruz de Carvalho Guilherme Henrique dos Santos Santana

Em síntese, percebe-se uma região diversa, visto que nem todos produtores adaptaram-se às novas tendências do agronegócio, afinal, mesmo com caráter homogeneizador, sempre existirão residualidades e tradicionalidades, caracterizando as marcas de um Brasil heterogêneo.

$\mathrm{Na}$ área de estudo, há uma grande quantidade de área plantada, bem como grandes quantidades de produção que, em um acompanhamento temporal, vêm crescendo a cada ano, reflexos das novas tecnologias e das melhorias do sistema de produção. Toda essa potência agropecuária leva a mudanças ao cotidiano das pessoas, altera as paisagens, definem novos fluxos e, como grande característica, modificam o Espaço Geográfico

\section{Agradecimentos}

Pesquisa financiada com recursos do edital Demanda Universal da Fundação de Amparo à Pesquisa do Estado de Minas Gerais - FAPEMIG ( ${ }^{\circ}$ 001/2017), registrado no processo APQ-01562-17. Neste sentido, os autores agradecem à FAPEMIG pelo incentivo ao desenvolvimento da pesquisa e sua divulgação.

\section{Nota}

${ }^{1}$ Pesquisa financiada com o apoio da Fundação de Amparo à Pesquisa do Estado de Minas Gerais FAPEMIG através do edital Demanda Universal (No 001/2017), registrado no processo APQ-01562-17. Salienta-se que o Prof. Dr. Marcelo Cervo Chelotti, Docente do Instituto de Geografia da Universidade Federal de Uberlândia, participou da produção desta Investigação acadêmica e sua respectiva divulgação.

\section{REFERÊNCIAS}

AMARAL, T. B.; PIRES, P. P.; DIAS, C. C.; LAMPERT, V. do N. Demandas Tecnológicas dos Sistemas de Produção de Bovinos de Corte no Brasil - Pecuária de Precisão. Campo Grande: Embrapa Gado de Corte, 2016. 28p. Disponível em: <http://www.cicarne.com.br/wp-content/uploads/2017/10/DOC221-Final-em-alta.pdf>. Acesso em: 29 novembro 2018.

BERNARDI, A. C. de C.; NAIME, J. de M.; RESENDE, A. V.; BASSOI, L. H.; INAMASU, R. Y. Agricultura de Precisão: resultado de um novo olhar. Brasília: Embrapa, 2014.

CASTANHO, R. B.; TEODORO, M. A. O uso das geotecnologias no estudo do espaço agropecuário. Brazilian Geographical Journal: Geosciences and Humanities research medium, Uberlandia, v. 1, n. 1, p.136-153, dez. 2010. 
CHELOTTI, M.C.; CASTANHO, R.B. (Org.) As múltiplas facetas do rural no

Triângulo Mineiro. Rio de Janeiro: Letra Capital, 2018.

CLEPS JR, J. Dinâmica e Estratégias do Setor Agroindustrial no Cerrado: o caso do Triângulo Mineiro. 291 f. Tese (Doutorado em Geografia) Universidade Estadual Paulista, 1998.

ELIAS, D. Globalização e Agricultura no Brasil. Geo UERJ Revista Departamento de Geografia, Rio de Janeiro, n.12, p.23-32, 2002.

ELIAS, D. Globalização e Agricultura: A região de Ribeirão Preto -SP. São Paulo: Edusp, 2003.

EMBRAPA. Geotecnologias e Geoinformação: o produtor pergunta, a Embrapa responde. Brasília: Embrapa, 2014. 248p.

FREDERICO, S. O novo tempo do Cerrado: Expansão dos fronts agrícolas e controle do sistema de armazenamento de grãos. São Paulo: Annablume, 2010.

GRAZIANO DA SILVA, J. A nova dinâmica da agricultura brasileira. Campinas: Unicamp, 1996.

GREGO, C. R.; ARAUJO, L. S. de; VICENTE, L. E.; NOGUEIRA, S. F.; MAGALHÃES, P. S. G.; VICENTE, A. K.; BRANCALIÃO, S. R.; VICTORIA, D. de C.; BOLFE, E. L. Agricultura de Precisão em Cana-de-Açúcar. IN: BERNARDI, A. C. de C.; NAIME, J. de M.; RESENDE, A. V. de; BASSOI, L. H.; INAMASU, R. Y (org.). Agricultura de Precisão: resultado de um novo olhar. Brasília: Embrapa, 2014. 596p. p. 442-457.

IBGE. Mapas. Disponível em: <https://mapas.ibge.gov.br/bases-e-referenciais/basescartograficas/malhas-digitais.html>. Acesso em: 30 agosto 2015.

IBGE. PAM. Disponível em: <https://sidra.ibge.gov.br/pesquisa/pam/tabelas>. Acesso em: 23 março 2019.

MARAFON, G. J. O trabalho decampo como um instrumento de trabalho para o investigador em geografia agrária. IN: RAMIRES, J. C. de L.; PESSÔA, V. L. S. (Org.). Geografia e pesquisa qualitativa: nas trilhas da investigação. Uberlândia: Assis, 2009, p. 379-394.

MARCONI, M. de A.; LAKATOS, E. M. Fundamentos de metodologia científica. $7^{\text {a }}$ ed. São Paulo. Atlas S.A, 2010.

PREZENTE, W. L. O uso das Geotecnologias no Ensino da Geografia. Disponível em: <http://cac-php.unioeste.br/eventos/geofronteira/anais2011/Arquivos/Artigos/ ENSINO/Artigo47.pdf>. Acesso em: 11 novembro 2018.

ROSA, R. Geotecnologias na Geografia aplicada. RDG - Revista do Departamento de Geografia. São Paulo, v. 16, p. 81-90, 2005. 
SANTOS, M. A natureza do espaço: técnica e tempo. Razão e emoção. 2 ed. São Paulo: HUCITEC, 1997.

Técnica Espaço Tempo: Globalização e meio técnico-cientifico informacional. São Paulo: HUCITEC, 1994.

Por uma outra globalização: do pensamento único à consciência universal.

20 ed. Rio de Janeiro: Record, 2011

SZMRECSÁNYI, T. Pequena História da Agricultura no Brasil: Do escravismo ao trabalho livre, estrutura agrária e relações de trabalho, para onde vai a Agroindústria? São Paulo: Contexto, 1997.

TEIXEIRA, M. E. S. Metamorfose do Espaço Agrário na Microrregião Geográfica de Ituiutaba nos Anos de 1970 a 2010. 111f. Trabalho de Conclusão de Curso (Graduação em Geografia) - Faculdade de Ciências Integradas do Pontal, Universidade Federal de Uberlândia, 2017.

Recebido em 06/12/2019.

Aceito para publicação em 24/04/2020. 